\title{
Plasma Volume in Cirrhosis of the Liver: Its Relation to Portal Hypertension, Ascites, and Renal Failure*
}

\author{
Fred L. Lieberman and Telfer B. Reynolds $\dagger$ \\ (From the Hepatic Service of the John Wesley County Hospital, Los Angeles, Calif. and the \\ University of Southern California School of Medicine, Los Angeles, Calif.)
}

\begin{abstract}
Summary. Plasma volume was measured by using albumin-131 I- and ${ }^{51} \mathrm{Cr}$ labeled erythrocytes in 24 control subjects, 140 patients with hepatic cirrhosis, and 10 patients with various portal-systemic shunts for the relief of noncirrhotic portal hypertension. The cirrhotic patients included subgroups with ascites, functional renal failure, and portacaval anastomoses. Elevated values for plasma volume, by both methods, were found in each group of patients.

The lymph space drained by the thoracic duct was measured by a radioisotopic technique in six patients with cirrhosis and ascites. The amount of radioactivity in this space was found to be negligible in accounting for the elevated plasma volume. Similar results were obtained when the degree of leakage of albumin-131 I into the ascites was determined in 10 patients with cirrhosis.

The plasma volume was unusually elevated in patients who had bled from esophageal varices, and paired comparisons before and after portacaval shunt normal values. There was a statistically significant correlation between normal values. There was a statistically significant correlation between plasma volume and wedged hepatic venous pressure measured in 36 patients.

We concluded that the elevated values for plasma volume in cirrhosis are valid and are not artifacts due to leakage of albumin- ${ }^{131}$ I from the circulation during mixing. We also concluded that portal hypertension is responsible for the plasma volume expansion; however, we were unable on this basis to explain the failure of portacaval shunting to return the plasma volume to normal, unless the shunt or some other factor keeps the plasma volume elevated.
\end{abstract}

\section{Introduction}

Renal sodium retention in cirrhosis is considered by many to be a response to hypovolemia resulting from formation of ascites (1-5). Furthermore, the suggestion has been made that a decrease in plasma volume may also account for the

* Submitted for publication November 28, 1966; accepted April 20, 1967.

Supported by research grant HE09316 from the $\mathrm{Na}$ tional Institutes of Health, U. S. Public Health Service.

† Address requests for reprints to Dr. T. B. Reynolds, Dept. of Medicine, University of Southern California School of Medicine, 2025 Zonal Avenue, Los Angeles, Calif. 90033. functional type of renal failure that is being recognized with increasing frequency in cirrhotic patients with ascites $(6,7)$. Even though the values for plasma volume in cirrhosis with ascites have been reported as elevated (8-14), it has been postulated that this elevation is due to distention of the splanchnic bed and hepatic lymphatics, obscuring a decrease in the nonportal or "effective" plasma volume $(2,15)$. It is, of course, possible that plasma volume measurements in ascitic patients are artifactually high because of leakage of the albumin label into the ascites or hepatic lymph during mixing. Although significant leakage into the ascites during the period required for plasma 
volume measurement has been discounted (16, 17 ), no assessment has yet been made of the degree of leakage into the lymph space.

In this paper we reconfirm the validity of the elevated plasma volume found in the ascitic cirrhotic patient by comparing measurements in a large population of cirrhotic patients both with and without ascites and, therefore, with and without clinical evidence of plasma leakage. Furthermore, our results indicate that the degree of leakage of albumin-131I from the plasma into the lymph space drained by the thoracic duct is negligible in accounting for this elevation. Finally, evidence will be presented to support portal hypertension as the cause of the elevated plasma volume in cirrhosis.

\section{Methods}

One hundred seventy-four patients were studied. Plasma volume was measured simultaneously with albumin- ${ }^{131} \mathrm{I}$ - and ${ }^{51} \mathrm{Cr}$-labeled red cells in 150 patients and with albumin- ${ }^{131} \mathrm{I}$ alone in 24 patients. Twenty-four (16 male, 8 female) were control patients, most of whom were semiambulatory and convalescing from various orthopedic procedures; 63 (44 male, 19 female) had cirrhosis without ascites; 34 (22 male, 12 female) had cirrhosis with ascites; 48 ( 33 male, 15 female) had cirrhosis and an end-to-side or side-to-side portacaval anastomosis for the relief of portal hypertension (14 of these patients had coexisting ascites despite documented patency of the shunt during life or at autopsy in five) ; 10 (6 male, 4 female) did not have cirrhosis but had a variety of surgical portal-systemic venous shunts for unexplained portal hypertension or portal hypertension associated with partial or complete extrahepatic portal venous occlusion (18); and 15 (13 male, 2 female) had cirrhosis and ascites complicated by functional renal failure $(6,19-21)$. Twenty-two of the 63 patients without ascites and one of the 34 patients with ascites had bled from esophageal varices several months before plasma volume measurement and were awaiting portacaval shunt surgery when plasma volume was measured. Plasma volume was measured by albumin $-{ }^{181} \mathrm{I}$ alone in 21 of these patients. Repeat measurements with albumin- ${ }^{181} \mathrm{I}$ were made in $18 \mathrm{pa}$ tients 6 months after end-to-side portacaval anastomosis, and the values are included in the mean plasma volume of the group of 34 patients with portacaval anastomoses without ascites. Almost all patients with cirrhosis had a history of chronic alcoholism, and moderate to advanced liver disease was present in all as judged by needle or surgical liver biopsy in 119 , necropsy in 10 who had not undergone biopsy before death, and physical examination and standard biochemical tests in all patients. All patients with ascites were on a diet containing $20 \mathrm{mEq}$ of sodium daily when plasma volume was measured.
For the measurement of red cell volume, $30 \mathrm{ml}$ of venous blood from each patient was labeled with $100 \mu \mathrm{c}{ }^{51} \mathrm{Cr}$ at room temperature in sterile containers with ACD anticoagulant ${ }^{1}$ added. The reaction was stopped after 30 minutes by adding $50 \mathrm{mg}$ ascorbic acid (22), and a weighed $20-\mathrm{ml}$ unwashed sample was returned intravenously. After 30 minutes, blood was withdrawn from the opposite arm and oxalated, and 1-ml samples of whole blood and plasma were weighed and counted in a scintillation well counter. The red cell volume was calculated as recommended by Silver (23), using microhematocrit readings determined by the method of McGovern, Jones, and Steinberg (24). The hematocrit was corrected for trapped plasma by multiplying each reading by 0.96 (25) ; to convert whole blood weight to volume, the specific gravity of each specimen was determined by the copper sulfate technique (26). In order to calculate plasma volume from the red cell mass, we corrected the peripheral venous hematocrit for trapped plasma and for the "total body": peripheral venous hematocrit ratio, which was arbitrarily taken to be 0.91 in each patient (27). In fact, if our plasma volume measurements with albumin- ${ }^{131} I$ are accurate, this ratio is highly variable and its mean is less than 0.91 in patients with cirrhosis, as will be discussed below.

For the direct measurement of plasma volume, a background reading, which was always negligible, was taken on the 30 -minute ${ }^{51} \mathrm{Cr}$-labeled plasma sample, and approximately $20 \mu \mathrm{c}$ of albumin- ${ }^{131} \mathrm{I}$ was injected intravenously when the 30-minute sample was drawn. A 2-ml calibrated syringe was used for injection, and an identical amount of albumin- ${ }^{131} \mathrm{I}$ was injected into an albumincoated water-filled 2-L volumetric flask. A single sample of blood was withdrawn 20 minutes after the intravenous administration of albumin- ${ }^{131} \mathrm{I}$, and duplicate $1-\mathrm{ml}$ samples of plasma were weighed and counted and a single $1-\mathrm{ml}$ sample of standard was weighed and counted in duplicate, each for 6 minutes or 10,000 counts in a well scintillation counter. For the conversion of the plasma weight to volume, the specific gravity of plasma was assumed to be 1.030 .

Because of the distorted weight in patients with cirrhosis and ascites, plasma volume and red cell volume were expressed in all patients in milliliters per kilogram based on ideal weight, calculated according to the formula of Lorentz (28), $\mathrm{P}=\mathrm{T}-100-(\mathrm{T}-150) / 4$, in which $\mathrm{P}$ is the ideal weight in kilograms and $T$ is the height in centimeters. The mean ideal weights for the control and study patients were not significantly different, as indicated in Table I (29).

In six patients with ascites, the plasma volume obtained with a single 20 -minute sample was compared with that obtained by extrapolating the logarithm of disappearance of activity over 60 minutes to zero time. Although slightly but consistently higher values were obtained with the 20 -minute sample, as expected (mean 2,150 $\pm 155 \mathrm{ml}$

\footnotetext{
1 Prepared by Abbott Laboratories, North Chicago, I1l., and E. R. Squibb \& Sons, New York, N. Y.
} 


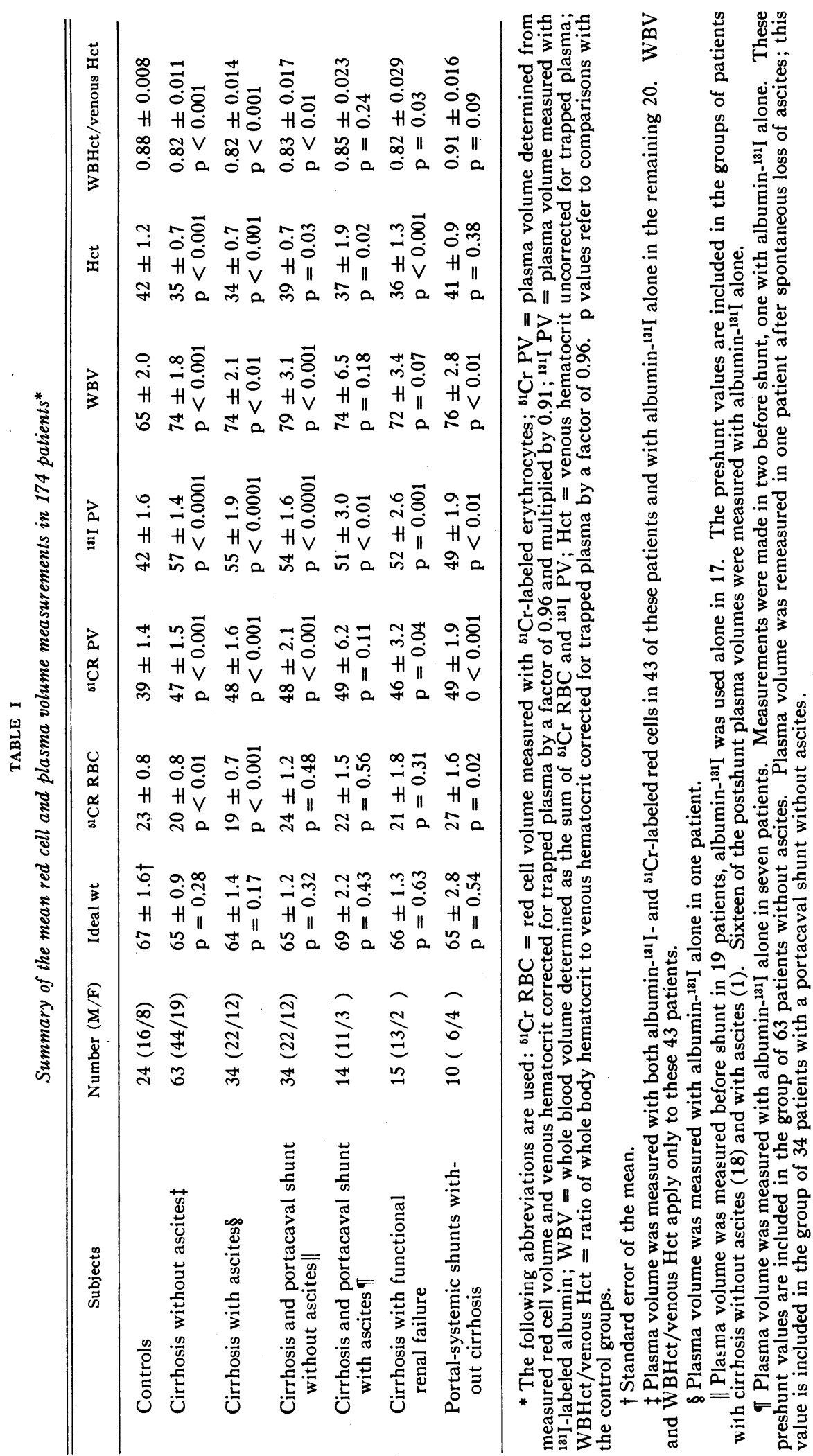


$\mathrm{SEM}^{2}$ vs. $2,080 \pm 167, \mathrm{p}=0.76$ ), it was felt that the values were close enough to justify using the simpler single sample method exclusively. Plasma volume measurement by this method is reproducible as indicated by a mean of $4,200 \mathrm{ml}$ with a standard error of $57 \mathrm{ml}$ for ten consecutive weekly 20 -minute plasma volume determinations in one patient with stable cirrhosis without ascites. His thyroid gland had previously been ablated by radioactive iodine therapy for hyperthyroidism.

Plasma volume measured with albumin- ${ }^{131} \mathrm{I}$ was compared with wedged hepatic venous pressure available in 33 of the 63 cirrhotic patients without ascites, and in three of the 34 patients with ascites. Wedge pressure was measured with a catheter passed under fluoroscopic vision via a vein in the antecubital fossa into the hepatic vein. The catheter was connected to a pressure recorder by means of a Statham strain gauge transducer. The average of pressures measured in at least two hepatic venous radicles, wedging being confirmed by hypaque injection (31), was referred to the inferior vena caval pressure as a zero reference point. Normal wedged pressure is considered to be less than $11 \mathrm{~mm} \mathrm{Hg} \mathrm{(32)} \mathrm{above} \mathrm{inferior}$ vena caval pressure.

The method of Bradley, Marks, Reynell, and Meltzer (33) for measuring the normal circulating splanchnic plasma volume in man was adapted to measure the volume of the lymph space drained by the thoracic duct in six patients with cirrhosis undergoing thoracic duct drainage for the treatment of ascites. In Bradley's method for determining the splanchnic volume, the appearance of intravenously injected albumin ${ }^{-131} \mathrm{I}$ is measured in blood leaving the splanchnic system in the hepatic vein, and its appearance and decline are measured in blood entering the splanchnic system represented by activity in the brachial or femoral artery. Measurements are continued until equilibrium is reached, as indicated by the equivalence of activity in the two vessels. The number of counts in the splanchnic bed at equilibrium is found by determining the hepatic plasma flow with Bromsulphalein and multiplying this by the difference in mean brachial arterial and hepatic venous plasma activities from injection to equilibrium, and by the number of seconds from injection to equilibrium. Dividing the equilibrium concentration into this number gives the splanchnic plasma volume. Similarly, when we measured the volume of the lymph space drained by the thoracic duct, we measured the appearance of activity of intravenously injected albumin $-{ }^{131} \mathrm{I}$ every 10 minutes in thoracic duct lymph after cannulation of the thoracic duct with the patient under local anesthesia; we measured its appearance and decline in plasma from the adjacent jugular vein. Because of a longer equilibrium time, the venous plasma activity can be used instead of arterial plasma activity; to obtain the activity entering the lymph space, we multiplied plasma activity by the ratio of lymph to plasma albumin. This ratio can be determined either by chemical means or by the equilibrium activity ratio of lymph to plasma from previously

2 All \pm values given in the remainder of the paper are standard errors of the mean. administered albumin- ${ }^{131} \mathrm{I}$. Measurements were made until equilibrium had been achieved between lymph and corrected plasma activity. Thoracic duct lymph flow was determined by allowing the cannula to drain lymph via gravity into a measuring bottle on the floor. The volume in milliliters of the lymph space drained by the thoracic duct was calculated as follows: (tdlf $(p-1) t) / e$, where $\operatorname{tdlf}=$ thoracic duct lymph flow in milliliters per minute; $p=$ mean corrected plasma activity to equilibrium; $1=$ mean thoracic duct lymph activity to equilibrium; $\mathrm{t}=$ minutes from injection to equilibrium; $\mathrm{e}=$ equilibrium activity.

\section{Results}

A summary of all plasma, red cell, and whole blood volume measurements is found in Table I. Whole blood volume is expressed as the sum of the red cell volume determined with ${ }^{51} \mathrm{Cr}$-labeled red cells and the plasma volume determined with albumin- ${ }^{131} \mathrm{I}$.

The mean plasma volume, determined with albumin-131 I, for the control patients was $42 \pm 1.6$ $\mathrm{ml}$ per $\mathrm{kg}$, which is similar to the mean plasma volume of a group of normal men and women studied by Steinfeld (34) and for normal men studied by Berson (16). For patients with cirrhosis with and without ascites, mean plasma volume was $55 \pm 1.9$ and $57 \pm 1.4 \mathrm{ml}$ per $\mathrm{kg}$, respectively. For patients with cirrhosis and portacaval anastomoses with and without ascites, it was $51 \pm 3.0$ and $54 \pm 1.6 \mathrm{ml}$ per $\mathrm{kg}$, respectively; for patients without cirrhosis but with portal-systemic venous anastomoses, it was $49 \pm 1.9 \mathrm{ml}$ per $\mathrm{kg}$.

The mean red cell volume, determined with ${ }^{51} \mathrm{Cr}$-labeled red cells, for the control patients was $23 \pm 0.8 \mathrm{ml}$ per $\mathrm{kg}$. For patients with cirrhosis with and without ascites, it was $19 \pm 0.7$ and $20 \pm 0.8 \mathrm{ml}$ per $\mathrm{kg}$, respectively. For patients with cirrhosis and portacaval anastomoses with and without ascites, it was $22 \pm 1.5$ and $24 \pm 1.2$ $\mathrm{ml}$ per $\mathrm{kg}$, respectively; for patients without cirrhosis but with portal-systemic venous anastomoses, it was $27 \pm 1.6 \mathrm{ml}$ per $\mathrm{kg}$.

The mean whole blood volume for the control patients was $65 \pm 2.0 \mathrm{ml}$ per $\mathrm{kg}$. For patients with cirrhosis with and without ascites, it was $74 \pm 2.1$ and $74 \pm 1.8 \mathrm{ml}$ per kg, respectively. For patients with cirrhosis and portacaval anastomoses with and without ascites, it was $74 \pm 6.5$ and $79 \pm 3.1$ $\mathrm{ml}$ per $\mathrm{kg}$, respectively; and for patients without cirrhosis but with portal-systemic venous anastomoses, it was $76 \pm 2.8 \mathrm{ml}$ per $\mathrm{kg}$. 
Compared to the mean plasma volume for the control patients, the mean plasma volume (albumin- $\left.{ }^{131} \mathrm{I}\right)$ for patients with cirrhosis and ascites was significantly elevated $(\mathrm{p}<0.0001)$. For patients with cirrhosis but without ascites, the mean plasma volume was also significantly elevated ( $p$ $<0.0001$ ) and not different from the value for patients with ascites $(p=0.40)$. Also, in patients with cirrhosis who had portacaval anastomoses without ascites, and who presumably had a decrease in intrahepatic as well as splanchnic congestion as a result of this operation, the mean plasma volume was significantly elevated $(p<0.0001)$. This elevation occurred even in those patients with side-to-side portacaval anastomoses, which are thought to decongest the liver maximally $(35,36)$ (Figure 1). Those 14 patients with cirrhosis who had portacaval anastomoses proven to be patent at autopsy in four and by catheterization in one, yet who had coexisting ascites, also had an elevated mean plasma volume $(51 \pm 3.0 \mathrm{ml}$ per $\mathrm{kg}$, $\mathrm{p}<0.01$ ) (Figure 1).

The red cell volume was slightly lower than normal in our patients with cirrhosis with and without ascites ( $p<0.001$ and $<0.01$, respectively), and it is possible that part of the plasma volume elevation in these patients was a compensatory response to prevent hypovolemia. However, the whole blood volume, which is the sum of the plasma volume (albumin- ${ }^{131} \mathrm{I}$ ) and the red cell volume $\left({ }^{51} \mathrm{Cr}\right)$ should account for such a compensatory increase in plasma volume (37). Since the control whole blood volume was $65 \pm 2.0 \mathrm{ml}$ per $\mathrm{kg}$ and that of patients with cirrhosis with and without ascites $74 \pm 2.1$ and $74 \pm 1.8 \mathrm{ml}$ per $\mathrm{kg}$, respectively, ( $\mathrm{p}<0.01$ and $<0.001$, respectively), it seems safe to conclude that the plasma volume is elevated in patients with cirrhosis for reasons other than anemia. Furthermore, the patients with portacaval shunts without ascites had a normal red cell volume $(24 \pm 1.2 \mathrm{ml}$ per $\mathrm{kg}$, $p=0.48)$, yet still had an elevated plasma and whole blood volume $(\mathrm{p}<0.0001$ and $<0.001$, respectively).

The mean values for plasma, red cell, and whole blood volume in patients without cirrhosis but with surgical portal-systemic venous anastomoses were $49 \pm 1.9,27 \pm 1.6$, and $76 \pm 2.8 \mathrm{ml}$ per $\mathrm{kg}$, re-

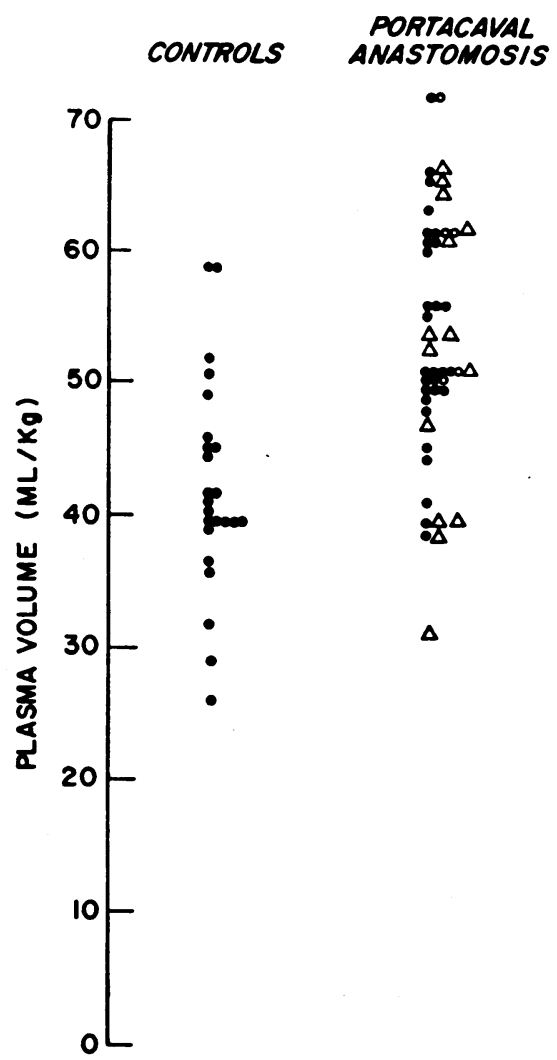

Fig. 1. Plasma volume measured with albumin- ${ }^{181}$ I in 24 CONTROL SUBJECTS AND IN 48 PATIENTS WITH CIRRHOSIS AND PORTACAVAL ANASTOMOSES. The patients depicted by closed circles had end-to-side anastomoses; those depicted by open circles had side-to-side anastomoses: The open triangles depict patients with end-toside anastomoses complicated by ascites. The mean values for the shunt and control groups were $54 \pm 1.4$ and $42 \pm 1.6 \mathrm{ml}$ per $\mathrm{kg}(\mathrm{SEM})(\mathrm{p}<0.0001)$.

spectively. Each of these values is significantly elevated from that of the control patients ( $p$ $<0.01, \mathrm{p}=0.02$, and $\mathrm{p}<0.01$, respectively).

Indirect measurement of plasma volume calculated from the red cell volume and the hematocrit was $39 \pm 1.4 \mathrm{ml}$ per $\mathrm{kg}$ in the control patients and, for patients with cirrhosis with and without ascites, $48 \pm 1.6$ and $47 \pm 1.5 \mathrm{ml}$ per $\mathrm{kg}$, respectively. Both of these values are significantly elevated ( $p<0.001$ in each instance). The lower plasma volumes obtained by the ${ }^{51} \mathrm{Cr}$-labeled red cell method compared with albumin- ${ }^{131} \mathrm{I}$ in patients with and without ascites $(48 \pm 1.6 \mathrm{ml}$ per $\mathrm{kg}, 47$ $\pm 1.5 \mathrm{ml}$ per $\mathrm{kg}$ vs. $54 \pm 1.6$ and $53 \pm 1.5 \mathrm{ml}$ per 
TABLE II

Ratio of ascites to plasma radioactivity 20 minutes after intravenous injection of albumin-131I

\begin{tabular}{lc}
\hline \multicolumn{1}{c}{ Patient } & Ascites activity $\times 100$ \\
\hline Uncomplicated ascites: & \\
E.G. & 0.0 \\
J.A. & 0.6 \\
B.R. & 1.1 \\
E.E. & 0.0 \\
T.N. & 0.6 \\
PCA* and ascites : & \\
R.G. & 0.6 \\
M.M. & 0.6 \\
Functional renal failure: & \\
E.C. & 1.5 \\
J.M. & 0.2 \\
L.M. & 0.9 \\
\hline
\end{tabular}

* Portacaval anastomosis.

$\mathrm{kg},{ }^{3}$ respectively) are probably due to an abnormally low whole body: peripheral venous hematocrit ratio in cirrhosis, as will be discussed below.

\section{Evidence against the elevated plasma volume being}

an artifact due to leakage of albumin-131I from the plasma during mixing

Leakage into ascites. Ascites radioactivity was simultaneously measured with that of the plasma in 10 patients with cirrhosis 20 minutes after the intravenous administration of albumin- ${ }^{131} \mathrm{I}$. Three of the patients had ascites complicated by functional renal failure, two had patent end-to-side portacaval anastomoses, and the remainder had

${ }^{3}$ These latter two means differ from those in Table I because they do not include the values of those patients whose plasma volumes were measured by albumin $-{ }^{131} I$ alone. uncomplicated ascites. The per cent activity of the ascites with respect to plasma for each of these patients is recorded in Table II ; for the 10 patients the mean was $0.6 \pm 0.16 \%$. Assuming that the volume of ascites was as high as five times the plasma volume (e.g., $15 \mathrm{~L}$ of ascites with a $3-\mathrm{L}$ plasma volume), the total injected activity in the ascites at 20 minutes would be approximately $3 \%$.

Leakage into lymph. The data obtained during sampling of thoracic duct lymph after the intravenous injection of albumin-131 I are recorded in Table III, and a representative equilibrium curve is shown in Figure 2. The mean lymph flow was $4.3 \mathrm{ml}$ per minute, which compares with a stated

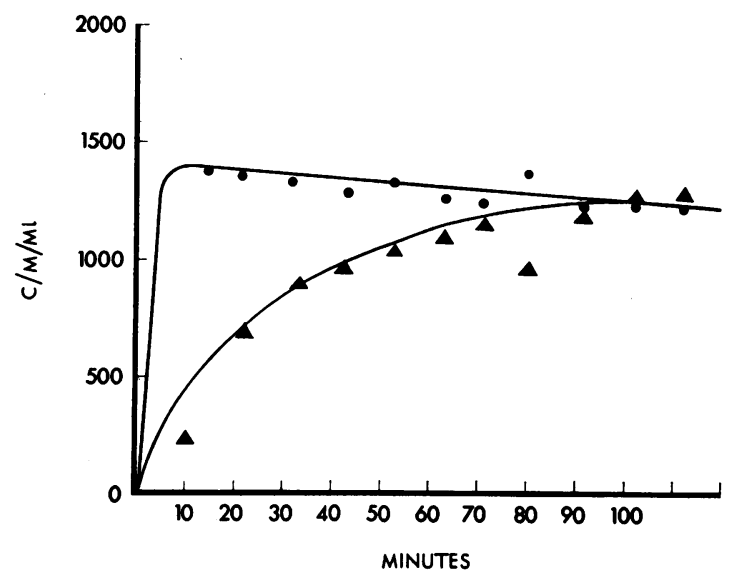

Fig. 2. Appearance of activity of intravenously INJECTED ALBUMIN- ${ }^{131}$ I IN THORACIC DUCT LYMPH (TRIANGLES) AND ITS DISAPPEARANCE FROM THE PLASMA (CLOSED CIRCLES) IN A PATIENT WITH CIRRHOSIS AND AScites. $\mathrm{C} / \mathrm{M} / \mathrm{ML}$ represents counts per minute per milliliter fluid. Plasma activity has been multiplied by the ratio of lymph albumin to plasma albumin to obtain the activity entering the lymphatic space.

TABLE III

Thoracic duct lymph measurements in six patients with ascites

\begin{tabular}{|c|c|c|c|c|c|c|c|c|c|}
\hline Patient & $\begin{array}{c}\text { Lymph } \\
\text { flow }\end{array}$ & $\begin{array}{c}\text { Mean } \\
\text { corrected } \\
\text { plasma } \\
\text { activity* }\end{array}$ & $\begin{array}{c}\text { Mean } \\
\text { lymph } \\
\text { activity }\end{array}$ & $\begin{array}{l}\text { Equilib- } \\
\text { rium } \\
\text { time }\end{array}$ & $\begin{array}{l}\text { Equilib- } \\
\text { brium } \\
\text { activity }\end{array}$ & $\begin{array}{l}\text { Lymph } \\
\text { albumin }\end{array}$ & $\begin{array}{l}\text { Plasma } \\
\text { albumin }\end{array}$ & $\begin{array}{c}\text { Plasma } \\
\text { volume }\end{array}$ & $\begin{array}{l}\text { TDł- } \\
\text { drained } \\
\text { Iymph } \\
\text { space }\end{array}$ \\
\hline & $m l / \min$ & \multicolumn{2}{|c|}{ counts $/ \mathrm{ml} / \mathrm{min}$} & $\min$ & counts $/ \mathrm{ml} / \mathrm{min}$ & \multicolumn{2}{|c|}{$\mathrm{gm} / 100 \mathrm{ml}$} & $m l$ & $m l$ \\
\hline E.R. & 1.43 & 2,260 & 1,858 & 80 & 2,091 & 1.5 & 1.8 & 2,120 & 22 \\
\hline M.H. & 4.93 & 1,963 & 1,393 & 30 & 1,904 & 1.2 & 2.3 & 2,190 & 44 \\
\hline J.A. & 5.80 & 1,273 & 905 & 100 & 1,220 & 0.7 & 1.8 & 2,680 & 175 \\
\hline M.S. & 5.32 & 1,279 & 1,018 & 60 & 1,175 & 0.5 & 2.5 & 1,740 & 71 \\
\hline E.G. & 2.32 & 1,315 & 854 & 60 & 1,275 & 0.9 & 2.6 & 1,510 & 51 \\
\hline B.C. & 6.12 & 1,136 & 775 & 80 & 1,023 & 1.2 & 2.3 & 2,240 & 172 \\
\hline
\end{tabular}

* Plasma activity multiplied by the ratio of lymph to plasma albumin concentration.

$\dagger$ Determined by extrapolating the logarithm of albumin-131I plasma disappearance to zero time.

$\ddagger$ Thoracic duct. 
normal value of approximately $1.0 \mathrm{ml}$ per minute (38). The average time for equilibrium to be achieved between plasma and lymph was 68 minutes, which compares with values in normal rats of 7 to 8 hours (39) and in normal dogs of 7 to 13 hours (40). The mean volume of the lymph space drained by the thoracic duct was calculated as 89 $\mathrm{ml}$, which amounts to $4.3 \%$ of the mean plasma volume for the six patients. The total activity in this space at 20 minutes is found by multiplying the 20-minute lymph activity by the volume of the lymph space; it is expressed as a per cent of the total injected activity for each patient in Table IV. On the average it represented only $0.8 \%$ of this activity.

The altered total body: peripheral venous hematocrit ratio in cirrhosis. The total body hematocrit can be determined by adding the ${ }^{51} \mathrm{Cr}$-labeled red cell volume to the albumin- ${ }^{131}$ I plasma volume to obtain the whole blood volume and by dividing this sum into the ${ }^{51} \mathrm{Cr}$-labeled red cell volume. When this ratio in turn is divided by the peripheral hematocrit corrected for trapped plasma, the resultant ratio has been found to vary from 0.89 to 0.92 in various groups of normal subjects (27). The mean ratio was 0.88 in our control patients and 0.91 in those 10 patients with portal-systemic shunts without cirrhosis. However, it was low in all patients with cirrhosis (Table I), indicating that the normal preponderance of whole body plasma to red cells with respect to peripheral venous blood is exaggerated in cirrhosis. Larsen, Winkler, and Tygstrup have found that the ratio of hepatic plasma volume to hepatic red cell volume in patients with cirrhosis and end-to-side portacaval anastomoses accounts for only $20 \%$ of this preponderance (41). Low body: venous hematocrit ratios have been reported in other diseases $(42,43)$, and unless taken into account in

TABLE IV

Albumin-131I radioactivity in the lymph space drained by the thoracic duct 20 minutes after intravenous injection

\begin{tabular}{cc}
\hline \hline Patient & Albumin-121 I radioactivity \\
\hline & $\%$ \\
E.R. & 0.6 \\
M.H. & 1.0 \\
J.A. & 1.2 \\
M.S. & 0.3 \\
B.G. & 0.2 \\
\end{tabular}

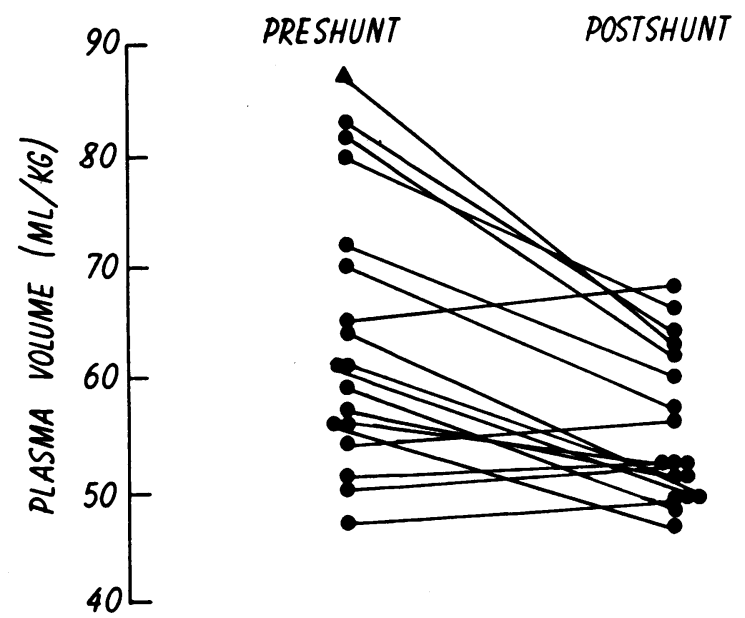

Fig. 3. Plasma volume measured with albumin- ${ }^{131} I$ BEFORE AND AFTER END-TO-SIDE PORTACAVAL SHUNT IN 18 CASES. One (triangle) had ascites when plasma volume was measured before shunt. The mean preshunt and postshunt volumes were $64 \pm 2.8$ and $55 \pm 1.4 \mathrm{ml}$ per $\mathrm{kg}$ $(p<0.01)$. The mean change in volume was $-9 \pm 1.9$ $\mathrm{ml}$ per $\mathrm{kg}(\mathrm{p}<0.01)$.

calculating total plasma volume from red cell volume and peripheral hematocrit, erroneously lower values for plasma volume will be obtained with the ${ }^{51} \mathrm{Cr}$-labeled red cell method.

\section{Plasma volume in functional renal failure}

Plasma volume was measured in 15 patients who had cirrhosis with ascites and what has been called, because of the lack of any consistent renal histopathology, "functional" renal failure $(6,19$ 21). Although the pathogenesis of this renal failure is poorly understood, Vesin has proposed that it develops as a result of decreased renal perfusion when effective plasma volume is reduced. $\mathrm{He}$ feels that during an ill-defined stage of cirrhosis with ascites, patients can no longer recoup their usually expanded plasma volume; in his experience, in patients seen for the first time at the stage of renal failure, the plasma volume was never increased, but corresponded to normal figures or was even below normal (6). Pequignot, Combrisson, Viallet, and Caroli have found that compared to that in a control group of 63 patients, the mean blood volume was lower in a group of 74 cirrhotic patients with hyperazotemia associated with a variety of problems such as gastrointestinal bleeding, peritonitis, and sepsis, and with diuretic therapy and paracentesis (7). 


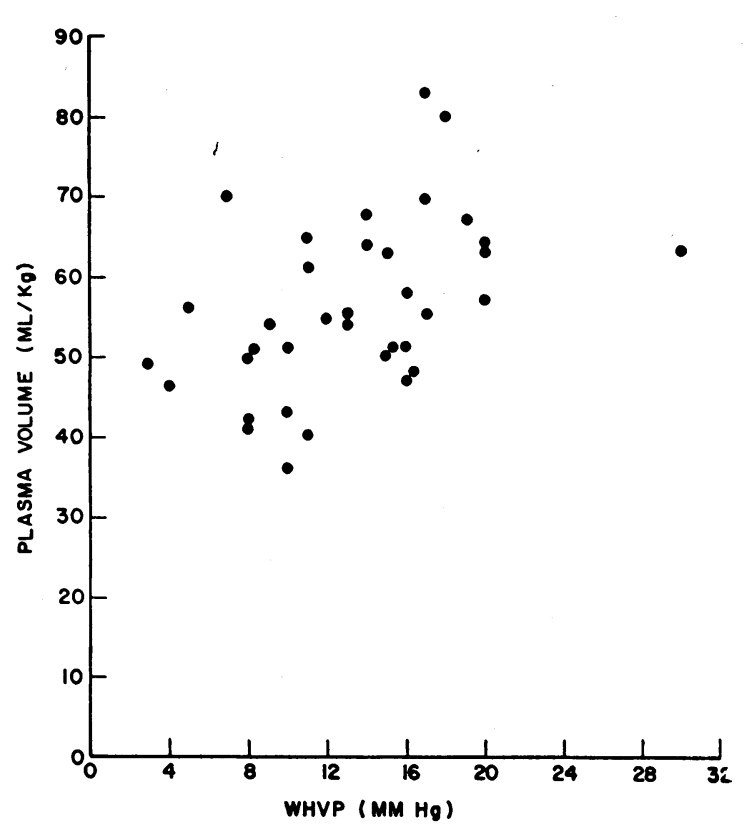

Fig. 4. Plasma volume, measured with albumin ${ }^{131}$ I AND WEDGED HEPATIC VENOUS PRESSURE COMPARED IN 36 PATIENTS With CIRRHOSIS. $r=+0.501, \mathrm{p}<0.05$.

The 15 patients studied here appeared to develop renal failure as part of the natural history of cirrhosis. All had ascites, and 14 died and were found to have normal kidneys at necropsy. None had suffered gastrointestinal hemorrhage before the recognition of renal failure, none had undergone paracentesis, and only four had undergone drug-induced diuresis, as judged by weight loss during a preceding period, which could reasonably be related to the renal failure. All were on a diet containing $20 \mathrm{mEq}$ of sodium daily when plasma volume was measured. The mean plasma volume for the 15 patients, using albumin- ${ }^{131} \mathrm{I}$ was $52 \pm 2.6 \mathrm{ml}$ per $\mathrm{kg}$, which is significantly elevated from that of the control patients $(42 \pm 1.6 \mathrm{ml}$ per $\mathrm{kg}, \mathrm{p}=0.001)$. Plasma volume was similarly elevated by the ${ }^{51} \mathrm{Cr}$-labeled red cell method ( $46 \pm 3.2$ vs. $39 \pm 1.4 \mathrm{ml}$ per $\mathrm{kg}, \mathrm{p}=0.04)$. There was no difference between the plasma volume of these patients and that of those with ascites uncomplicated by functional renal failure, whether measured with albumin- ${ }^{131} \mathrm{I}$ or indirectly with ${ }^{51} \mathrm{Cr}$-labeled red cells (albumin- ${ }^{131} \mathrm{I}, 52 \pm 2.6$ vs. $55 \pm 1.9 \mathrm{ml}$ per $\mathrm{kg}, \mathrm{p}=0.34 ;{ }^{\mathrm{51}} \mathrm{Cr}, 46 \pm 3.2$ vs. $48 \pm 1.6 \mathrm{ml}$ per $\mathrm{kg}, \mathrm{p}=0.58)$.

\section{Effect of portacaval shunt on plasma volume}

There was a mean decrease of $9 \pm 1.9 \mathrm{ml}$ per $\mathrm{kg}(\mathrm{p}=0.01$, Student $t$ test $)$ in plasma volume with albumin- ${ }^{131} \mathrm{I}$ before and 6 months after portacaval shunt in 18 patients (Figure 3 ). The mean values before and after shunt were $64 \pm 2.8$ and $55 \pm 1.4 \mathrm{ml}$ per $\mathrm{kg}$, respectively. There was a mean rise in hematocrit of $2.9 \pm 1.3 \%(\mathrm{p}<0.05)$.

\section{Comparison of wedged hepatic venous pressure and plasma volume}

There was a definite correlation between wedged hepatic venous pressure and plasma volume measured with albumin- ${ }^{131} \mathrm{I}(\mathrm{r}=+0.501, \mathrm{p}<0.05)$. The individual values are plotted in Figure 4.

\section{Discussion}

If the elevated plasma volume measured with albumin- ${ }^{131} \mathrm{I}$ in the presence of ascites were solely an artifact due to leakage of the radioactivity from the plasma during mixing, we would expect to find a lower plasma volume in patients without ascites. The factors favoring albumin leakage should be exaggerated in, if not limited to, the patients with ascites. The fact that the plasma volume measured with albumin- ${ }^{131} \mathrm{I}$ was the same whether or not ascites was present suggests that these measurements in the fluid-retaining stage of cirrhosis are valid. Furthermore, if significant leakage of albumin- ${ }^{131} \mathrm{I}$ from the plasma occurred during mixing, the plasma volume calculated from the hematocrit and the red cell volume determined with ${ }^{51} \mathrm{Cr}$-labeled red cells should be normal. The finding of an elevated plasma volume by both methods in patients with and without ascites provides confirmation of the validity of the elevated values determined with albumin- ${ }^{131} \mathrm{I}$.

The use of ideal weight based on height might have biased our results in favor of an increase in plasma volume in cirrhosis with ascites, if the mean ideal weight for these patients constitutes an underestimation of dry weight. However, this appears unlikely because of the large number of patients studied, which minimizes individual variation in dry weight, and because there was no appreciable difference in the mean ideal weights of these patients and the control patients.

The findings of 3 and $\frac{8}{10} \%$ of intravenously injected albumin-131 I in the ascites and in the 
lymph space drained by the thoracic duct, respectively, provide direct confirmation of a negligible leak of albumin- ${ }^{131} \mathrm{I}$ from the plasma during the period required to measure plasma volume. Others have also found a slow exchange of albumin between plasma and ascites in cirrhosis (16, $17,30,44)$.

Although the lymph space we have calculated may be smaller than previously advanced concepts of its magnitude in cirrhosis $(15,45)$, we believe it is probably a reasonable, though approximate, figure. Even if there were pathways other than the thoracic duct for return of lymph to the plasma $(46,47)$, such pathways would create a situation in which the proposed method for measuring the lymphatic space would produce a spuriously elevated, not reduced, volume.

From the foregoing comparison of plasma volume in patients with and without ascites, and from the direct assessment of the degree of leakage of albumin- ${ }^{131} \mathrm{I}$ into ascites and lymph during mixing, we have concluded that the elevated plasma volume in cirrhosis with ascites is real, not an artifact due to leakage of albumin- ${ }^{131} \mathrm{I}$ from the plasma during mixing.

Perera (8) and others $(10,11)$ have proposed that the elevated plasma volume in hepatic cirrhosis is due to an expanded portal venous bed, which necessitates an expansion of the plasma volume to fill it. Decompression of this hypertensive portal system by portacaval anastomosis should then theoretically return the plasma volume to normal. However, all investigators find the plasma volume to be elevated in the presence of a portacaval shunt, whether end-to-side $(12,28)$ or side-to-side (48). Murray, Dawson, and Sherlock (12), in addition, have found a normal mean plasma volume in six patients with histologically normal livers but with portal hypertension due to extrahepatic portal venous occlusion. They therefore question the role of portal hypertension in the expansion of plasma volume in cirrhosis and offer an alternative proposal that the expansion is due to the presence of systemic as well as hepatic arteriovenous fistulas thought to occur in cirrhosis. They cite the well-known finding of slightly elevated plasma volumes in patients with traumatic arteriovenous fistulas (49). Their data, however, have not been confirmed by Boyer and co-workers, who reported an elevated mean plasma volume in nine patients with extrahepatic portal venous block (50).

Our own data suggest that portal hypertension is the cause of the plasma volume increase in cirrhosis. The relief of portal hypertension by portacaval anastomosis was accompanied by a definite fall in plasma volume, although not to normal values. Other workers have also measured plasma volume before and after portal decompression, and have obtained similar results. Combrisson, Bonnet, and Hivet (28), using chromium-labeled red cells and measuring plasma volume indirectly from peripheral venous hematocrit, found the mean plasma volume to be $139 \%$ of normal before shunt in five patients with cirrhosis, and $136 \%$ after endto-side portacaval shunt. Even, Nicollo, Benhamou, and Fauvert (51), also using chromiumlabeled red cells, found no statistical difference in the mean whole blood volume in 12 patients with cirrhosis before and after end-to-side portacaval shunt. However, if the plasma volume is calculated in each of their patients from the peripheral hematocrit, there was a mean decrease of $9 \pm$ $3.4 \%$, which is statistically significant $(p<0.03$, Student $t$ test). In seven of 12 of McDermott's patients undergoing "double barrel" or side-to-side portacaval shunt for the treatment of ascites (48), plasma volume can be related to ideal body weight based on height. When so expressed, the mean values before and after shunt were $68 \pm 6$ and $51 \pm 5 \mathrm{ml}$ per $\mathrm{kg}$.

Because portal hypertension and bleeding from esophageal varices seem intimately related, our finding of an unusually high plasma volume in patients undergoing portacaval shunt because of bleeding varices $(64 \pm 2.8 \mathrm{ml}$ per $\mathrm{kg})$ also supports a causal relationship between portal hypertension and plasma volume elevation. Of the group of 63 patients with cirrhosis free of ascites, 22 had bled from esophageal varices several months before plasma volume was measured. The mean plasma volume for these 22 patients was $63 \pm 2.0 \mathrm{ml}$ per $\mathrm{kg}$ compared to $53 \pm 1.4$ for the remaining 41 patients $(p<0.0001)$ who had not bled from varices.

Finally, the finding of a positive correlation between wedged hepatic venous pressure and plasma volume, though not providing proof of a causal relationship between portal hypertension and 
plasma volume elevation in cirrhosis, adds additional support for this concept.

If we accept portal hypertension as the cause for the increased plasma volume in cirrhosis, we must account for our data and those of others $(12,28$, 48 ), which show hypervolemia after portacaval anastomosis. The following three possibilities occur to us : 1) The portacaval anastomosis, by decreasing hepatic blood flow, might keep the plasma volume from falling to normal. Evidence has been presented recently to show that hepatic degradation of aldosterone is dependent on liver blood flow (52-54), and it is possible that a reduction in hepatic blood flow produced by portacaval anastomosis of either the end-to-side or side-to-side variety (36) could elevate the plasma aldosterone concentration sufficiently to keep the plasma volume expanded.

2) The portacaval anastomosis, by allowing a relatively large flow of blood through an area of low resistance, may be acting like a large arteriovenous fistula and may thus provide an alternative reason for continuation of plasma volume expansion despite portal venous decompression.

Either of these explanations might account for the increased plasma volume in our 10 noncirrhotic patients who had a variety of portal-systemic venous anastomoses for the relief of portal hypertension. The mean values by the albumin- ${ }^{-131} \mathrm{I}$ and ${ }^{51} \mathrm{Cr}$-labele red cell techniques were $49 \pm 1.9$ and $49 \pm 1.9 \mathrm{ml}$ per $\mathrm{kg}$, respectively, which are significantly elevated above the values of the control patients.

3) Increased intrahepatic pressure may be a stimulus for aldosterone secretion, as proposed by Orloff and co-workers (55), and the degree of intrahepatic pressure elevation that remains after portacaval shunt (32) may be a sufficient stimulus for continued plasma volume expansion, despite complete relief of portal hypertension by the shunt.

\section{Acknowledgments}

We are indebted to Dr. William Hammond for performing the thoracic duct cannulations, Dr. Ryugo Hidemura for performing the wedged hepatic venous pressure measurements, and to Mr. Richard Suzuki for technical assistance in the blood volume measurements. We are also grateful to Miss Helen Russell and Mrs. Patricia Peck for preparing the manuscript, and to Mrs. Lynda Dümmel for the illustrations.

\section{References}

1. Eisenmenger, W. J., S. H. Blondheim, A. M. Bongiovanni, and $H$. G. Kunkel. Electrolyte studies on patients with cirrhosis of the liver. J. clin. Invest. 1950, 29, 1491.

2. Eisenmenger, W. J. Role of sodium in the formation and control of ascites in patients with cirrhosis. Ann. intern. Med. 1952, 37, 261.

3. Gabuzda, G. J., Jr., H. S. Traeger, and C. S. Davidson. Hepatic cirrhosis : effects of sodium chloride administration and restriction and of abdominal paracentesis on electrolyte and water balance. J. clin. Invest. 1954, 33, 780.

4. Sherlock, S., and S. Shaldon. The aetiology and management of ascites in patients with hepatic cirhosis: a review. Gut 1963, 4, 95.

5. Wolfman, E. F., Jr., R. S. Kowalczyk, and G. Trevino. Salt, water and adrenal steroid metabolism in The Liver and Portal Hypertension, C. G. Child III. Philadelphia and London, W. B. Saunders, 1964, pp. 152-175.

6. Vesin, P. Late functional renal failure in cirrhosis with ascites: pathophysiology, diagnosis and treatment in Aktuelle Problems der Hepatologie, G. A. Martini, Ed. Stuttgart, Georg. Thieme Verlag, 1962, pp. 98-109.

7. Pequignot, G., A. Combrisson, A. Viallet, and J. Caroli. Hypovolémie relative des cirrhotiques avec hyperazotémie (Rôle déclenchant des diurétiques). Arch. Mal. Appar. dig. 1962, 51, 744.

8. Perera, G. A. The plasma volume in Laennec's cirrhosis of the liver. Ann. intern. Med. 1946, 24, 643.

9. Bateman, J. C., H. M. Shorr, and T. Elgvin. Hypervolemic anemia in cirrhosis. J. clin. Invest. 1949, 28, 539 .

10. Hiller, G. I., E. R. Huffman, and S. Levey. Studies in cirrhosis of the liver. I. Relationship between plasma volume, plasma protein concentrations, and total circulating proteins. J. clin. Invest. 1949, 28, 322.

11. Eisenberg, S. Blood volume in patients with Laennec's cirrhosis of the liver as determined by radioactive chromium-tagged red cells. Amer. J. Med. 1956, 20, 189.

12. Murray, J. F., A. M. Dawson, and S. Sherlock. Circulatory changes in chronic liver disease. Amer. J. Med. 1958, 24, 358.

13. Ofstad, J. The bearing of portal vein congestion on the state of the circulation in cirrhosis of the liver. Acta med. scand. 1960, 168, 77.

14. Dykes, P. W. A study of the effects of albumin infusions in patients with cirrhosis of the liver. Quart. J. Med. 1961, 30, 297.

15. Papper, S. The role of the kidney in Laennec's cirrhosis of the liver. Medicine (Baltimore) 1958, 37, 299.

16. Berson, S. A. Blood volume in health and disease. Bull. N. Y. Acad. Med. 1954, 30, 750. 
17. Moir, T. W., W. H. Pritchard, and A. B. Ford. Early disappearance of $\mathrm{I}^{131}$ serum albumin from the circulation of edematous subjects and its implications in the clinical determination of the blood volume. J. Lab. clin. Med. 1956, 47, 503.

18. Mikkelsen, W. P., H. A. Edmondson, R. L. Peters, A. G. Redeker, and T. B. Reynolds. Extra- and intrahepatic portal hypertension without cirrhosis (hepatoportal sclerosis). Ann. Surg. 1965, 162, 602.

19. Hecker, R., and S. Sherlock. Electrolyte and circulatory changes in terminal liver failure. Lancet 1956, 2, 1121.

20. Papper, S., J. L. Belsky, and K. H. Bleifer. Renal failure in Laennec's cirrhosis of the liver. I. Description of clinical and laboratory features. Ann. intern. Med. 1959, 51, 759.

21. Baldus, W. P., R. M. Feichter, and W. H. J. Summerskill. The kidney in cirrhosis. I. Clinical and biochemical features of azotemia in hepatic failure. Ann. intern. Med. 1964, 60, 353.

22. Read, R. C. Studies of red-cell volume and turnover using radiochromium: description of a new "closed" method of red-cell-volume measurement. New Engl. J. Med. 1954, 250, 1021.

23. Silver, S. Radioactive isotopes in clinical medicine. New Engl. J. Med. 1965, 272, 515.

24. McGovern, J. J., A. R. Jones, and A. G. Steinberg. The hematocrit of capillary blood. New Engl. J. Med. 1955, 253, 308.

25. Gregersen, M. I. Blood volume. Ann. Rev. Physiol. $1951,13,397$.

26. Philips, R. A., D. D. Van Slyke, P. B. Hamilton, V. P. Dole, K. Emerson, Jr., and R. M. Archibald. Measurement of specific gravities of whole blood and plasma by standard copper sulfate solutions. J. biol. Chem. 1950, 183, 305.

27. Chaplin, H., Jr., P. L. Mollison, and H. Vetter. The body/venous hematocrit ratio: its constancy over a wide hematocrit range. J. clin. Invest. 1953, 32, 1309.

28. Le -Bolloc 'h-Combrisson, A., J. L. Bonnet, and M. Hivet. Le volume sanguin apres shunt porto-cave direct termino-lateral. Rev. méd.-chir. Mal. Foie 1963, 38, 203.

29. Hill, A. B. Principles of Medical Statistics, 7th ed. New York, Oxford University Press, 1961.

30. Bauer, F. K., W. H. Blahd, M. Fields, and G. Getchell. Ascitic fluid and plasma protein exchange in cirrhosis of the liver. Studies with radioiodinated human serum albumin and gamma globulin. Metabolism 1954, 3, 289.

31. Reynolds, T. B., A. G. Redeker, and H. M. Geller. Technique for verification of wedging of a hepatic venous catheter (abstract). Gastroenterology 1960, 38, 799.

32. Redeker, A. G., H. M. Geller, and T. B. Reynolds. Hepatic wedge pressure, blood flow, vascular resistance and oxygen consumption in cirrhosis be- fore and after end-to-side portacaval shunt. J. clin. Invest. 1958, 37, 606.

33. Bradley, S. E., P. A. Marks, P. C. Reynell, and J. Meltzer. The circulating splanchnic blood volume in dog and man. Trans. Ass. Amer. Phycns 1953, 66, 294.

34. Steinfeld, J. L. Difference in daily albumin synthesis between normal men and women as measured with $\mathrm{I}^{181}$-labeled albumin. J. Lab. clin. Med. 1960, 55, 904.

35. Warren, W. D., and W. H.' Muller, Jr. A clarification of some hemodynamic changes in cirrhosis and their surgical significance. Ann. Surg. 1959, 150, 413.

36. Redeker, A. G., C. T. Kunelis, S. Yamamoto, and T. B. Reynolds. Assessment of portal and hepatic hemodynamics after side-to-side portacaval shunt in patients with cirrhosis. J. clin. Invest. 1964, 43, 1464.

37. Gibson, J. G., 2d, A. W. Harris, and V. W. Swigert. Clinical studies of the blood volume. VIII. Macrocytic and hypochromic anemias due to chronic blood loss, hemolysis and miscellaneous causes, and polycythemia vera. J. clin. Invest. 1939, 18, 621.

38. Dumont, A. E., and J. H. Mulholland. Flow rate and composition of thoracic-duct lymph in patients with cirrhosis. New Engl. J. Med. 1960, 263, 471.

39. Abdou, I. A., W. O. Reinhardt, and H. Tarver. Plasma protein. III. The equilibrium between blood and lymph protein. J. biol. Chem. 1952, 194, 15.

40. Wasserman, K., and H. S. Mayerson. Exchange of albumin between plasma and lymph. Amer. J. Physiol. 1951, 165, 15.

41. Larsen, O. A., K. Winkler, and N. Tygstrup. "Extra" plasma in the liver calculated from the hepatic hematocrit in patients with portacaval anastomosis. Clin. Sci. 1963, 25, 357.

42. Berson, S. A., and R. S. Yalow. The use of $\mathrm{K}^{42}$ or $P^{32}$ labeled erythrocytes and $I^{131}$ tagged human serum albumin in simultaneous blood volume determinations. J. clin. Invest. 1952, 31, 572.

43. Hope, A., and D. Verel. Further observations on the distribution of red cells and plasma in disease - the low body hematocrit: venous haematocrit ratio. Clin. Sci. 1955, 14, 501.

44. Schoenberger, J. A., G. Kroll, A. Sakamoto, and R. M. Kark. Investigation of the permeability factor in ascites and edema using albumin tagged with $\mathrm{I}^{181}$. Gastroenterology 1952, 22, 607.

45. Baggenstoss, A. H., and J. C. Cain. The hepatic hilar lymphatics of man: their relation to ascites. New Engl. J. Med. 1957, 256, 531.

46. Paldino, R. L., and C. Hyman. Alternative pathways for the return of lymph. Amer. Heart J. 1964, 67, 280.

47. Pressman, J. J., M. V. Burtz, and L. Shafer. Further observations related to direct communications between lymph nodes and veins. Surg. Gynec. Obstet. 1964, 119, 984. 
48. McDermott, W. V., Jr. The double portacaval shunt in the treatment of cirrhotic ascites. Surg. Gynec. Obstet. 1960, 110, 457.

49. Warren, J. V., D. C. Elkin, and J. L. Nickerson. The blood volume in patients with arteriovenous fistulas. J. clin. Invest. 1951, 30, 220.

50. Boyer, J. L., K. P. Sen Gupta, S. K. Biswas, N. C. Pal, K. C. Basu Mallick, F. L. Iber, and A. K. Basu. Idiopathic portal hypertension. Comparison with the portal hypertension of cirrhosis and extrahepatic portal vein obstruction. Ann. Intern. Med. 1967, 66, 41.

51. Even, P., F. Nicollo, J. P. Benhamou, and R. Fauvert. Le debit cardiaque au cours des maladies du foie. Effets de l'anastomose porto-cave et des diuretiques. Révue int. Hépat. 1966, 16, 955.
52. Tait, J. F., J. Bougas, B. Little, S. A. S. Tait, and C. Flood. Splanchnic extraction and clearance of aldosterone in subjects with minimal and marked cardiac dysfunction. J. clin. Endocrinol. 1965, 25, 219.

53. Yates, F. E. Contributions of the liver to steadystate performance and transient responses of the adrenal cortical system. Fed. Proc. 1965, 24, 723.

54. Davis, J. O., M. J. Olichney, T. C. Brown, and P. F. Binnion. Metabolism of aldosterone in several experimental situations with altered aldosterone secretion. J. clin. Invest. 1965, 44, 1433.

55. Orloff, M. J., C. A. Lipman, S. M. Noel, N. A. Halasz, and $T$. Neesby. Hepatic regulation of aldosterone secretion by a humoral mediator. Surgery 1965, 58, 225. 